Original Article

\title{
ANATOMICAL CHARACTERIZATION OF MEDICINAL PLANTS USING FOLDSCOPE: A PAPER BASED ORIGAMI MICROSCOPE-(NEW DIAGNOSTIC TOOL)
}

\author{
SHARMILA S. ${ }^{1 *}$, RAMYA E. K. ${ }^{2}$, MOWNIKA S. ${ }^{3}$ \\ ${ }^{1,2,3 *} \mathrm{PG}$ and Research Department of Botany, Vellalar College for Women (Autonomous), Thindal, Erode 638012, Tamilnadu, India \\ Email: drsharmilas@yahoo.com
}

Received: 12 Aug 2019, Revised and Accepted: 10 Oct 2019

\begin{abstract}
Objective: This study mainly focussed how foldscope can be used as an efficient viewable tool to detect in morphological and anatomical investigation of various bioactive medicinal plants. Microscope provides a beneficial instrument for visualization of living cells. Its cost is very high which is not affordable for rural based educational institutes. Foldscope is the ultra-affordable and versatile, paper microscope designed to be
\end{abstract} extremely portable, durable and to give optical quality similar to conventional research microscopes.

Methods: For enhancing scientific temperament among rural children, Indian Born Scientist (Dr. Manu Prakash) has introduced an ultra-low-cost foldable origami-based approach for large-scale manufacturing of microscope, specifically demonstrating bright field, dark field and fluorescence microscopes. However, its potential as in research tool in the area of aromatic medicinal plants is still not known. The slides were prepared by own and were observed with the magnification power of $140 \mathrm{X}$.

Results: The result of the present study reported that the Foldcsope images revealed viable stained areas in the respective plant parts like trichomes, stomata, pollen grains, stem and leaf of different medicinal plants and indicating their live activities.

Conclusion: Based on the attractive images captured from the Foldscope, the uses of foldscope were recommended to public. Previously we had organized some awareness cum demonstration programme regarding foldscope and its applications in the field of science education in the different educational institute of Erode District, Tamilnadu. Based on the clarity of images and easy handling of Foldscope the uses of origami microscope were recommended for higher studies.

Keywords: Foldscope, Anatomical, Medicinal plants, Origami, Paper microscope

(C) 2019 The Authors. Published by Innovare Academic Sciences Pvt Ltd. This is an open-access article under the CC BY license (http://creativecommons.org/licenses/by/4.0/) DOI: http://dx.doi.org/10.22159/ijcpr.2019v11i6.36335

\section{INTRODUCTION}

A Foldscope is an optical microscope that can be assembled from simple components, including a sheet of paper and a lens. It is a unique invention by an Indian scientist, Dr. Manu prakash, professor at Stanford University developed to foster deep interest in science at an early stage by providing "Microscope for every child". The foldscope is an ultra-affordable paper microscope inspired by origami. It is a portable, sturdy and versatile microscope made mostly out of paper (waterproof) that magnifies the wonders of the microscopic world, without the bulk and expense of a conventional research microscope [1]. Foldscope is designed to bring microscopy out of science labs and into the hands of people around the world. It is a real microscope, with magnification and resolution sufficient for imaging live individual cells, cellular organelles, embryos, swimming bacteria and much more. It is affordable and can be used anywhere. It brings science to daily life. It is part of the "frugal science" movement which aims to make cheap and easy tools available for scientific use in the developing world.

The Foldscope was developed by a team led by Dr. Manu Prakash, an Assistant Professor of Bioengineering at the Stanford School of Medicine. The project was funded by several organizations including the Bill and Melinda Gates Foundation, which gave a grant of US $\$ 100,000$ for research in November 2012. The basic principle of using a small spherical lens held close to the eye dates back to Antonie van Leeuwenhoek (1632-1723), who was the first to see single-celled organisms using such a lens held in a device of his own design. The idea for creating a low-cost microscope came to Prakash in 2011 while he was at a field station in Thailand. He remarked that the station had a very expensive microscope but that everyone was afraid to use it because it was fragile and worth more than most people's salaries. He wanted to create an affordable microscope that would be versatile and sturdy enough to work in the field conditions. The scientist also wanted to create a device that people felt they had ownership of, which is part of the reason the Foldscope comes in a kit to be assembled. The young scientist developed the first prototype microscope in 2014 [2]. In October 2015, India's Department of Biotechnology announced a program to make foldscopes available across India at 80 approved colleges and programs. It will be used as a teaching tool for students in biology, chemistry and physics. After the pilot program, the Department hopes to work with Prakash to develop more low-cost science research tools [3]. Foldscope sets will also be produced and tested in Kenya and Uganda. Later the newly distributed foldscope has microlens, with the potential of $140 \mathrm{X}$ magnification and $1.9 \mu \mathrm{m}$ resolution, would be useful for viewing and video recording microscopic data and pictures (with a smart phone-optional) in bright field, dark field and oblique phase illumination.

\section{MATERIALS AND METHODS}

For the review and documentation of medicinal plants, intensive exploration trips were conducted for one year from May 2018 to May 2019 in Manar beat, Karamadai range, Coimbatore District, The Western Ghats, Tamil Nadu (fig. 1). The vegetation of the study area is floristically rich compared to other regions and represents several unique habitats. The investigation was conducted in six small villages of Manar beat situated in Karamadai range, which are occupied by Irula tribals. Based on the tribes traditional knowledge, the active plant specimens were collected from the study area and were stored in polythene bags to prevent desiccation. The field data regarding their habit, habitat, phenology and flower colour etc. were noted down in the field note book. The collected plant species were identified with the help of existing Floras (The Flora of Presidency of Madras (Gamble and Fischer, 1957) and The Flora of Tamil Nadu Carnatic (Matthew, 1983). The identity is authenticated by matched with type specimens available in the herbarium of Botanical Survey of India, Southern Circle, TNAU Campus, Coimbatore, Tamilnadu. 


\section{Experimentation}

\section{Illustration of a diagnostic tool}

A Foldscope is an optical microscope that can be assembled from a punched sheet of cardstock, a spherical glass lens, a light-emitting diode and a diffuser panel, along with a watch battery that powers the LED [4]. Based on the lab light conditions, even normal sunlight or LED light can be used as light source. Once assembled, the Foldscope is about the size of a bookmark. The Foldscope weighs 8 grams and comes in a kit with multiple lenses that provide magnification from 140X to 2,000X [5]. The kit also includes magnets that can be stuck onto the foldscope to attach it to a Smartphone, allowing the user to take pictures of the magnification. Foldscope punched cards can be printed on a standard A4 sheet of paper and assembled in seven minutes duration [6]. Dr. Prakash claims that the Foldscope can survive harsh conditions, including being thrown in water or dropped from a five-story building (fig. 2) [7].

\section{Sectioning}

Free hand section of plant materials were used for the anatomical studies. These sections were mounted in glycerin stained with safranin. The paraffin-embedded specimens were sectioned with the help of Rotary Microtome. The thickness of the section was 10-12 $\mu \mathrm{m}$. Dewaxing of the sections was done by customary procedure [8]. The internal plant constants such as trichomes distribution, stomatal and pollen morphology, stem and leaf anatomy of different active medicinal plants were studied. Descriptive terms of the anatomical features are taken from the standard anatomy book [9].

\section{RESULTS}

The Foldscope is comprised of four stages cut from paper they are lens stage, sample stage, panning guide and focus ramp (fig. 3).
Other primary components include a spherical ball lens, lensholder apertures, an LED with diffuser or condenser lens, a battery, and an electrical switch. Plant materials were collected from the different locality of Manar beat and viewed by foldscope for anatomical characterization in field conditions. Anatomical examination was carried out in trichomes, stomata, pollen grains, stem and leaf of different medicinal plants shown in fig. 4 . Unicellular trichomes were seen in Acalypha indica and Passiflora foetida. Multicellular trichome was observed in Euphorbia hirta. Diacytic stomata were observed in Adathoda vasica, where else paracytic stomata were seen in Ixora coccinea. Morphology of pollen grains was captured in Tribulus terrestris. Transverse section of stem was examined in Acalypha indica, Adathoda vasica, Tribulus terrestris, Passiflora foetida and Catharanthus roseus. The wedge-shaped vascular bundles were viewed in Nerium odorum leaf.

We had demonstrated many programs at various educational institutions regarding "Foldscope assembly and its applications". Of these some workshops and hands-on training were conducted for the student community. Every session started with interaction on foldscope preparation and handling method along with some slides for the students to know the assembly and utility of the low-cost microscope, which can be attached to a smartphone to take photographs of the specimen. Later, a MoU was signed between Vellalar College for Women (Autonomous), Tamil Nadu with Mizoram University, Aizawl, Mizoram, India for effective teacher-student exchange programme. List of institutions (table 1), different demonstration and workshop photograph (fig. 4) and foldscope images (fig. 5) are given below. The foldscope images were uploaded in the website https://microcosmos.foldscope.com
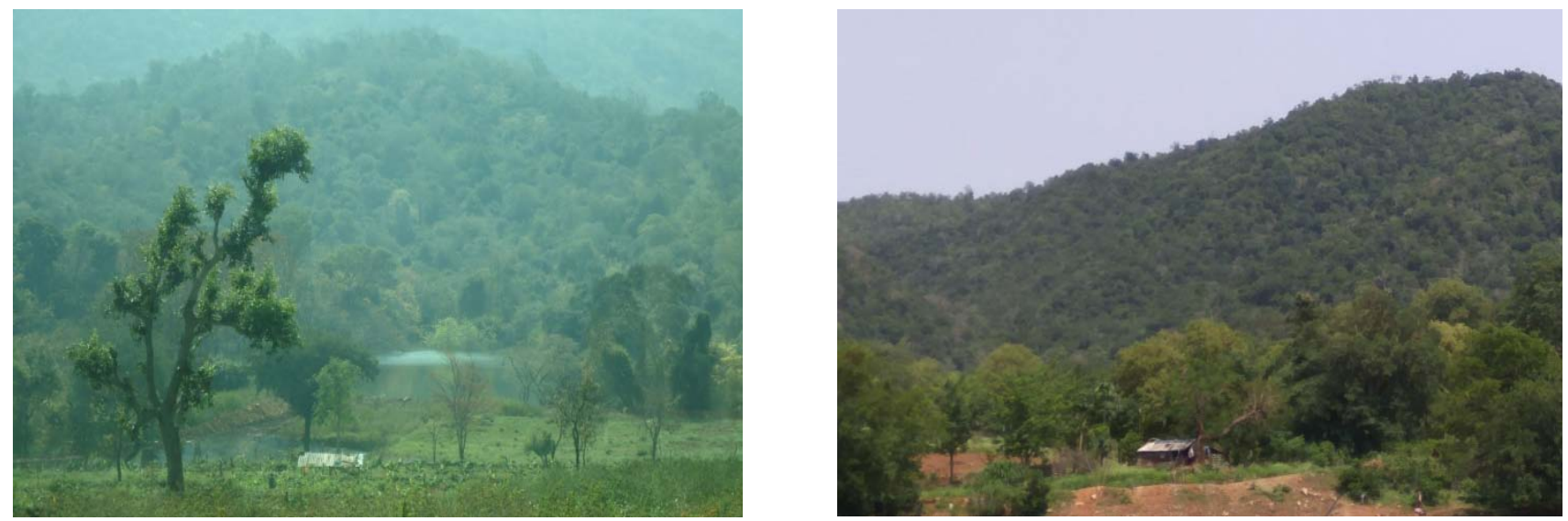

Fig. 1: Panoramic view of manar beat, karamadai range

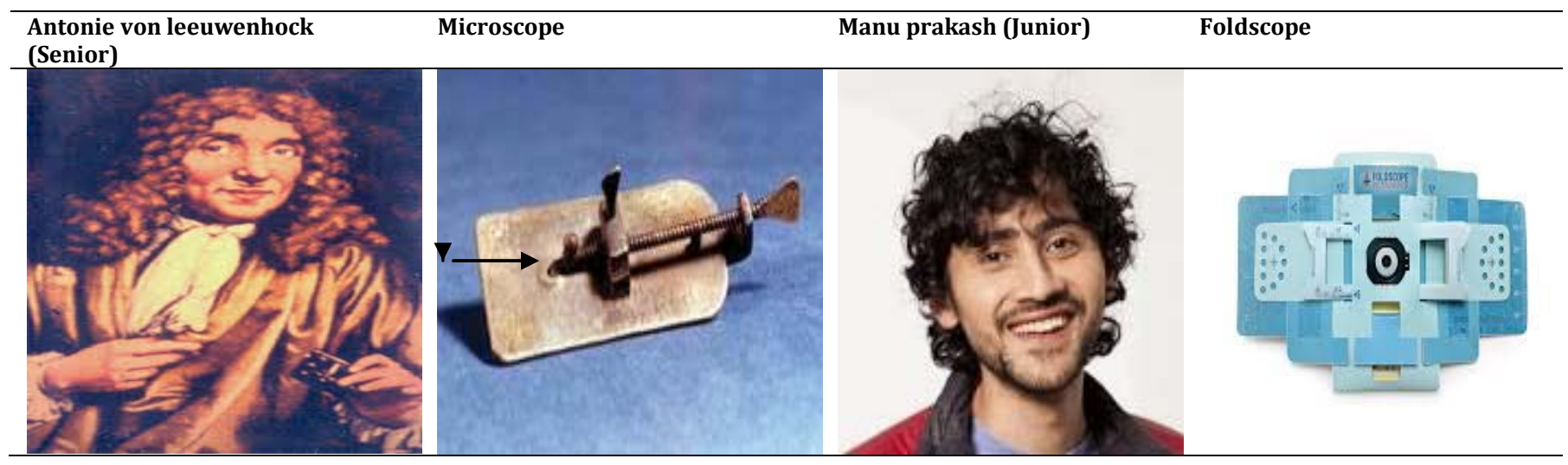

Fig. 2: Pioneers in microscopy 


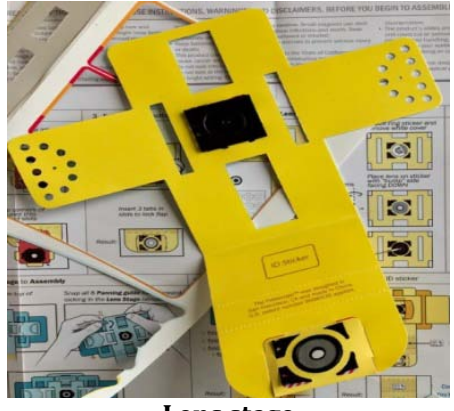

Lens stage

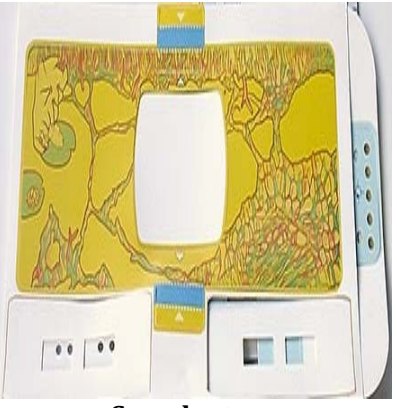

Sample stage

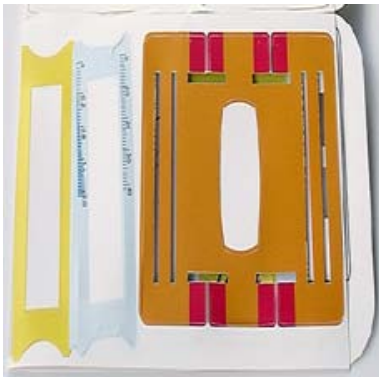

Panning guide

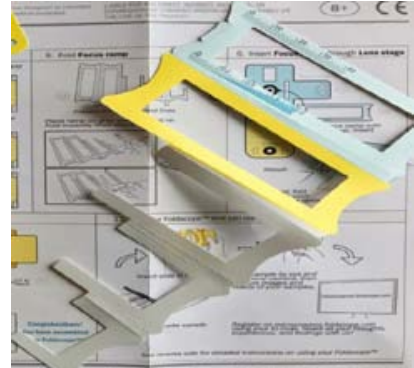

Focus ramp

Fig. 3: Four stages of foldscope

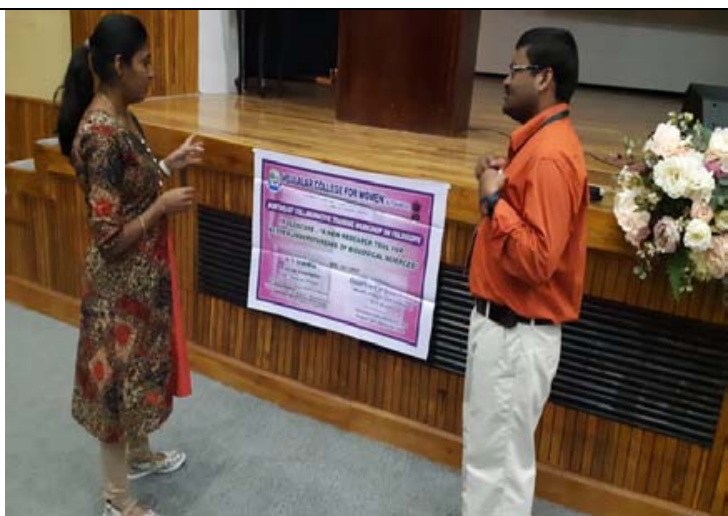

Explained the theme of Foldscope in Workshop at Mizoram University, Aizawl.


Introducing the foldscope to College Students, Vellalar College for Women, Erode, Tamil Nadu

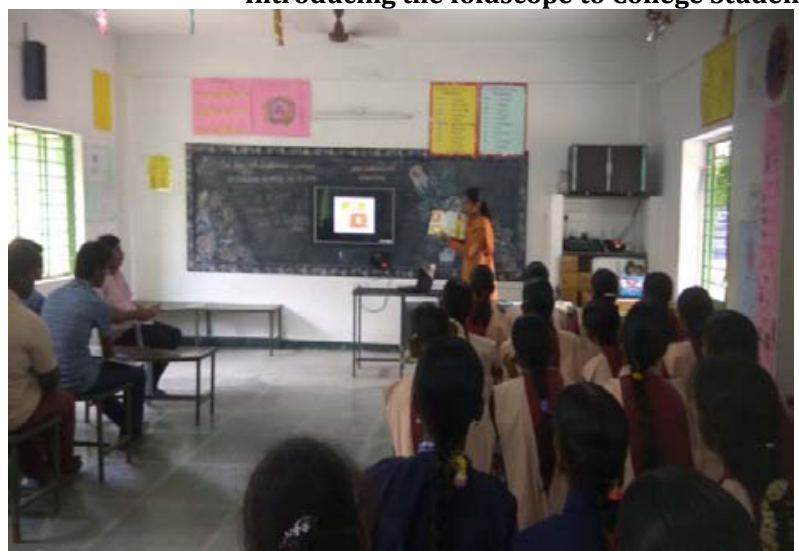

Assembly of origami paper microscope to school Students, Government Higher Secondary School, Vijayamangalam, Erode district, Tamil Nadu

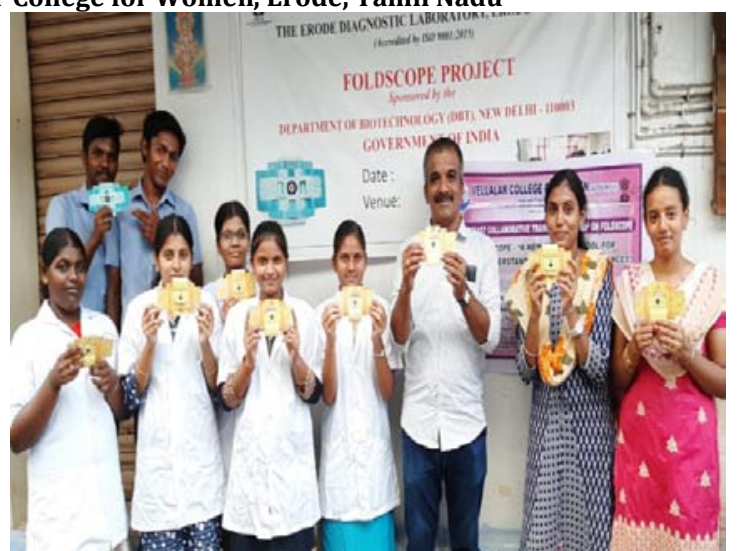

Foldscope workshop was conducted in e-lab, Erode, Tamil Nadu

Fig. 4: Workshop and training programmes at various institutes 







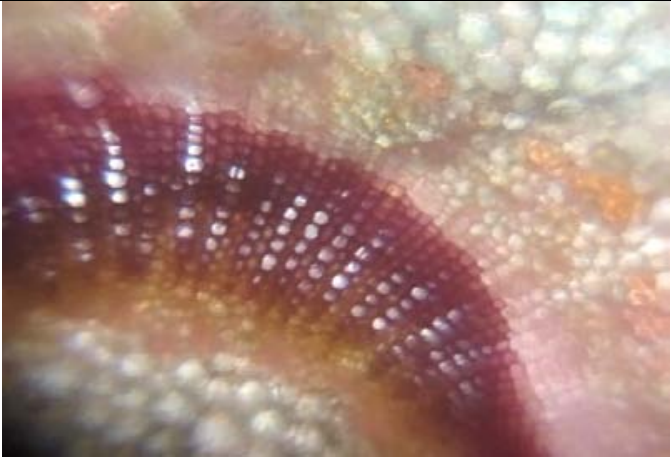

Catharanthus roseus (L.)G. Don Stem

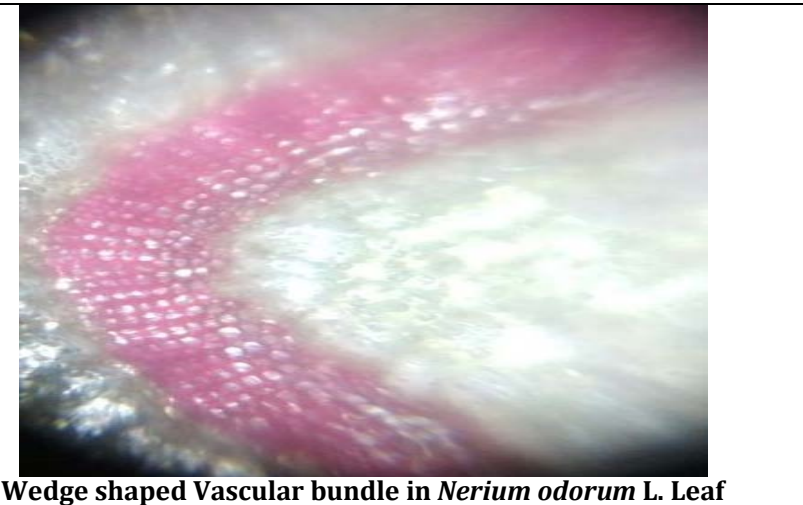

Wedge shaped Vascular bundle in Nerium odorum L. Lea

Fig. 5: Anatomical features of different medicinal plants-Foldscope view

Table 1: Foldscope Workshop-List of various institutions

\begin{tabular}{|c|c|c|c|c|}
\hline $\begin{array}{l}\text { S. } \\
\text { No. }\end{array}$ & Name of the institutions & Theme of the programme & Date of visit & $\begin{array}{l}\text { No. of students } \\
\text { participation }\end{array}$ \\
\hline 1. & $\begin{array}{l}\text { Government Higher Secondary School, } \\
\text { Vijayamangalam, Erode Dt, Tamil Nadu. }\end{array}$ & $\begin{array}{l}\text { One Day Skill Development Workshop on } \\
\text { Foldscope Assembly and its Usage }\end{array}$ & $8^{\text {th }}$ June 2018 & 60 \\
\hline 2. & $\begin{array}{l}\text { Vellalar College for Women, (Autonomous), } \\
\text { Erode Dt, Tamil Nadu. }\end{array}$ & Foldscope assembly and usage for UG students & $\begin{array}{l}11^{\text {th }} \text { September } \\
2018\end{array}$ & 145 \\
\hline 3. & $\begin{array}{l}\text { Government Boys Higher Secondary School, } \\
\text { Manickampalayam, Erode Dt, Tamil Nadu. }\end{array}$ & One Day foldscope training Programme & $16^{\text {th }}$ October 2018 & 50 \\
\hline 4. & $\begin{array}{l}\text { Vellalar College for Women, (Autonomous), } \\
\text { Department of Botany, Erode Dt, Tamil Nadu. }\end{array}$ & $\begin{array}{l}\text { Foldscope-A new research tool for better } \\
\text { understanding of Biological Sciences }\end{array}$ & $\begin{array}{l}13^{\text {th }} \text { November } \\
2018 .\end{array}$ & 30 \\
\hline 5. & $\begin{array}{l}\text { Vellalar College for Women, (Autonomous), } \\
\text { Department of Botany, Erode Dt, Tamil Nadu. }\end{array}$ & $\begin{array}{l}\text { Applications of Foldscope in Bioscience and } \\
\text { Ecosystem Biomonitoring through } \\
\text { Environmental DNA Metaborcoding approach }\end{array}$ & $10^{\text {th }}$ January 2019 & 40 \\
\hline 6. & $\begin{array}{l}\text { Research Committee, } \\
\text { Vellalar College for Women (Autonomous), } \\
\text { Erode Dt, Tamil Nadu. }\end{array}$ & Tools to Revitalize Research and Teaching & $\begin{array}{l}28^{\text {th }} \text { February } \\
2019\end{array}$ & 25 \\
\hline 7. & $\begin{array}{l}\text { Erode Diagnostic Laboratory, Erode Dt, Tamil } \\
\text { Nadu. }\end{array}$ & $\begin{array}{l}\text { Foldscope-A new scientific research kit for } \\
\text { simple indulgent of microbiological and } \\
\text { clinical sciences }\end{array}$ & $2^{\text {nd }}$ May 2019 & 10 \\
\hline
\end{tabular}

Table 2: Foldscope upload views-https://microcosmos.foldscope.com

\begin{tabular}{|c|c|c|c|c|}
\hline S. No. & Date & User name & Id-sticker No. & Title \\
\hline 1. & 5.6 .2018 & Dr. S. Sharmila & 0002D5F1A74E & Morphoanatomical characters of medicinal plants in Manar region \\
\hline 2. & 5.6 .2018 & Dr. S. Sharmila & 0002D5F1A74E & Litter study in Manar hill range \\
\hline 3. & 12.6 .2018 & Dr. S. Sharmila & 0002D5F1A74E & $\begin{array}{l}\text { One day DBT funded skill development workshop on foldscope assembly and its } \\
\text { usage }\end{array}$ \\
\hline 4. & 9.7 .2018 & E. K. Ramya & 0002D5F1A74E & $\begin{array}{l}\text { Isolation of litter decomposing microorganisms in Manar hill range-The Western } \\
\text { Ghats }\end{array}$ \\
\hline 5. & 23.7.2018 & S. Mownika & 0002BF1DCFDE & Specific focus on histological characterization-Medicinal plants in Manar range \\
\hline 6. & 13.8.2018 & S. Mownika & 0002BF1DCFDE & Recent approach to view stomatal anatomy under foldscope \\
\hline 7. & 11.09.2018 & Dr. S. Sharmila & 0002D5F1A74E & Rauvolfia serpentine and Acacia caesia anatomical view under foldscope \\
\hline 8. & 17.09.2018 & M. Anusha & $00023 \mathrm{DC} 2 \mathrm{FFB} 3$ & Workshop on "Foldscope assembly and usage for UG students" \\
\hline 9. & 11.10 .2018 & Yuvarajeswaran & 00020ACCD823 & $\begin{array}{l}\text { Foldscope vision of Passiflora foetida L.-a protocarnivorous plant in Mannar region, } \\
\text { Western Ghats, Tamil Nadu }\end{array}$ \\
\hline 10. & 17.10.2018 & Rosekavin & 0002227BD7A4 & $\begin{array}{l}\text { One-Day-Foldscope-Training Programme-in-Government-Boys Higher-Secondary- } \\
\text { School,-Manickampalayam, Erode, Tamilnadu }\end{array}$ \\
\hline 11. & 10.11.2018 & Sudhakar & $00025057 \mathrm{C} 6 \mathrm{~B} 6$ & $\begin{array}{l}\text { Outcome of Foldscope Workshop-Government Higher Secondary School, } \\
\text { Vijayamangalam, Erode District, Tamil Nadu }\end{array}$ \\
\hline 12. & 27.11.2018 & Dr. S. Sharmila & 0002D5F1A74E & Northeast collaborative Training Workshop on Foldscope \\
\hline 13. & 21.01.2019 & Dr. S. Sharmila & 0002D5F1A74E & Workshop on Foldscope Applications in Bioscience \\
\hline 14. & 23.01.2019 & Dhivyamani & 000238AAE022 & Foldscope anatomical view of Solanum trilobatum and Mukia maderaspatana \\
\hline 15. & 11.03 .2019 & Vinovinothini & 00020596A8BC & Pollen grains under Foldscope \\
\hline 16. & 12.03 .2019 & Dr. S. Sharmila & 0002D5F1A74E & Workshop on Foldscope-"Tools to Revitalize Research and Teaching" \\
\hline 17. & 03.05.2019 & $\begin{array}{l}\text { Kirithiga } \\
\text { Mythrayi }\end{array}$ & 0002D91127E6 & A Collaborative and Innovative Foldscope Workshop in Erode \\
\hline
\end{tabular}

\section{CONCLUSION}

Foldscope is a sparkling innovation technique. It paves ways for other such innovations for the replacement of costly scientific instruments.
Foldscope is an advanced technology developed in microscopic world that will help the people to understand the microscopic world troublously. Scientists like Dr. Manu Prakash have shown that simple and affordable scientific devices can be designed, fabricated for the use 
of common masses and can be made available in the remotest part of the world for scientific exploration which is very easy, useful and affordable for all mankind. Based on this data it was concluded that foldscope can be a cheap, portable and powerful efficient biological tool to evaluate plant biology-based studies. The foldscope was used as an educational and training tool to help students in various disciplines like Physics, Chemistry, Biology and instrumentation. The foldscope is mainly used to study floras and faunas. With the help of a foldscope we can study the plant anatomical view, microorganisms, pathogens, water samples etc.. Definitely our workshop instigates spark among rural students and also enrich the usage of this research tool in scientific field. We are eagerly waiting for the day that each basic biology practicals in school and college level should use this Foldscope as a research tool to update science among young minds.

\section{ACKNOWLEDGMENT}

The author is highly thankful to Department of Biotechnology (DBT) (under Ministry of Science and Technology, Government of India), Foldscope Instruments Inc. and Prakash Lab (Stanford) for funding the project and providing Foldscope micro-grant with origami microscope.

\section{AUTHORS CONTRIBUTIONS}

All the author have contributed equally.

\section{CONFLICT OF INTERESTS}

Declare none

\section{REFERENCES}

1. Cybulski JS, Clements J, Prakash M. Foldscope: the origamibased paper microscope. Plos One 2014;9:e98781.

2. A Microscope to Save the World. The New Yorker; 2015. p. 1222.

3. Coxworth Ben. Folding a paper microscope could reduce deaths from malaria. Gizmag; 2014.

4. Mathews, Lee "Foldscope is a 50-cent paper microscope that magnifies up to 2000 times". Geek. Com; 2014.

5. Wakefield, Jane. Ultra-cheap 'origami' microscope developed. BBC News; 2014.

6. Origami microscopes for college students across India-Nature India. Nat India; 2015. p. 133.

7. DBT-India. Microscopy for all: DBT brings Foldscope to underprivileged children; 2018.

8. Johansen DA. Plant microtechnique. New York: McGraw- Hill Book Co; 1940. p. 523.

9. Easu K. Plant anatomy of seed plants. John Wiley and Sons. New York; 1964. p. 767. 